\title{
AN AGENT-BASED MODEL TO EVALUATE HOUSING DYNAMICS OF COASTAL COMMUNITIES FACING STORMS AND SEA LEVEL RISE
}

\author{
Ayse Karanci ${ }^{1}$, Emily Berglund ${ }^{1}$ and Margery Overton ${ }^{1}$
}

\section{ABSTRACT}

\begin{abstract}
An agent-based model (ABM) is developed to explore the effects of storms and sea level rise (SLR) on soft-engineered coastal management actions and households' housing decisions at the coastal town of Nags Head in North Carolina, USA. The ABM links the behavior of household agents (individual homeowners) and town agents (coastal managers) with morphological coastal evolution caused by long-term erosion, sea level rise, and storms. Storm impacts are determined by combining the process-based model XBeach (Roelvink, 2009) outputs with the ABM framework. The integrated $\mathrm{ABM}$ framework is applied to simulate occupation dynamics and community viability under forcing from storms and sea level rise over a time frame of 50 years. A timeline with storm events was created using historical data and the intensity of the storm in the midpoint of the timeline was varied to explore the effect of storm intensity on the community. Simulations demonstrated a strong link between the intensity of storms and household occupancy. Results suggest that increased storm intensity hinders development and in some cases can cause community occupation growth to stagnate or decline. The results also indicate a feedback loop between the natural processes, management decisions, and household decisions. After a severe storm, buildings are damaged, expenses are increased, and occupation declines. A diminished community cannot invest in protection measures and in turn becomes more vulnerable to future storms. A tipping point may occur, where the community stagnates with respect to its household occupation. To investigate the influence of varying sea level rise rates on community occupancy dynamics, the model was forced with different sea level rise scenarios, including no sea level rise, a constant rate of sea level rise, and two scenarios with accelerated sea level rise. The scenario with no sea level rise showed a considerably more attractive community than the scenarios with sea level rise. This was attributed to (1) absence of expenses incurred in other scenarios to mitigate recession caused by sea level rise and (2) lower flooding risk.
\end{abstract}

Keywords: XBeach; coupled human-natural system modeling; community attractiveness; climate change

\section{INTRODUCTION}

Increasingly, coastal town managers have to develop efficient coastal management plans to address climate change. This is a difficult task given the complex nature of coastal towns. There are strong linkages and feedbacks between the coastal processes and human response require a tightly coupled natural and human management model.

Several studies have employed human-natural systems coupling to explore the implications of climate change for coastal towns (Murray et al., 2013; McNamara et al., 2015 and Waard 2016). Murray et al. (2013) estimated a decline in real estate market as a consequence of increasing sea levels. McNamara et al. (2015) demonstrated an instant fall in coastal property prices after the removal of government subsidies for beach nourishment and De Waard (2016) showed a decrease in property values as residents' information about climate change increased. These studies has emphasized gradual processes that modify such as long-term erosion and human manipulation of the coastal landscape, to mitigate the challenges caused by these conditions. While gradual changes at of coastal morphology do present significant economic challenges to coastal communities, storms can cause unexpected damages to structures and may cause sudden disruptions to community occupation. In the future, coastal communities are expected to face increased flooding risk during storms, due to sea level rise exacerbated by climate change. Sea level rise can increase the risks by moving the shoreline closer to structures, eroding protective features, and increasing the surge levels during storms. Aside from the increasing sea levels, past research has shown positive correlation between storm intensity and increasing sea temperatures (IPCC, 2013; Emanuel, 2005). Although these results are highly debated, the influence of storms on the households' occupation dynamics are clearly linked and should be included alongside the sea level rise phenomenon in coupled human-natural system modelling efforts which seeks to aid coastal management decisions under a changing climate.

In this study, agent-based modelling (ABM) (Railsback and Grimm, 2011) is used to establish a bottom-up analytical framework that links natural and human systems. The model which has been described previously in Karanci et al. (in press) uses storms and sea level rise as exogenous drivers and simulates the evolution of the morphological landscape, implementation of soft-engineered coastal

\footnotetext{
${ }^{1}$ Department of Civil, Construction and Environmental Engineering, North Carolina State University, Raleigh, NC, 27695, USA
} 
protection measures and household's housing decisions. The existing model utilizes an empirical formulation to predict the dune response to storms, which was determined by Hallermeier and Rhodes (1988) methodology, correlating storm surge to dune erosion from field data. There are two main objectives of this study. First, to improve the morphological modeling in the current model by introducing a framework to integrate XBeach (eXtreme Beach behaviour model)(Roelvink et al., 2009) a processbased storm impact model. In the model XBeach will be utilized instead of the Hallermeier and Rhodes (1998) methodology to simulate storm impact. Several studies have compared XBeach model results with the field measurements of beach and dune response to storm events (Van Dongeren et al. 2009; Splinter and Palmsten 2012) and showed that XBeach was able to successfully reproduce dune response during a storm. Consequently, inclusion of XBeach in the model framework is expected to improve the current estimation of storm impact.

The second objective is to use the updated version of the ABM including XBeach to explore the influence of storm intensity and sea level rise by modelling the response of households and town managers under alternative scenarios for the coastal town of Nags Head, North Carolina, USA. In the first set of scenarios, the model will be forced by a storm base timeline including one storm of increasing intensity while sea level rise conditions of all scenarios remain the same. These scenarios will be used to investigate the influence of storm intensity on community's coastal protection actions and household housing decisions. In a similar manner, to assess the possible impact of rising sea levels on household occupation, a second set of scenarios uses different sea level rise rates, including IPCC (2013) high and low emission scenario estimates, while using the storms of constant intensity through simulation.

The paper is structured as follows: first, the overall hydrodynamic conditions, past coastal protection actions, topography and housing demographics of the coastal community of Nags Head are presented. Next, the general model structure including the representation of the coastal community and data requirements are explained. This is followed by a detailed description of each process and decision in the model, including the integration of XBeach into the ABM framework to simulate morphological changes. The data required to represent Nags Head is reviewed and the development of multiple storm surge and water level timelines, each spanning 50 years, is articulated. The model results for these scenarios are presented and a discussion of the model and its limitations concludes this paper.

\section{STUDY AREA}

The study area is the Town of Nags Head, North Carolina, USA, located on the Outer Banks barrier island chain. Nags Head is a popular tourist destination for families and attracts sunbathers and coastal sports enthusiasts. With an area of $17.2 \mathrm{~km}^{2}$, Nags Head encompasses $18 \mathrm{~km}$ of ocean shoreline along the Atlantic Ocean.

The town is selected as the study area because: (1) it has experienced storms during last century, (2) it is subjected to coastal erosion and sea level rise, (3) it has carried out coastal protection projects, and (4) it is located $25 \mathrm{~km}$ south of the U.S. Army Corps of Engineers (USACE) Field Research Facility (FRF) with over 29 years of historical wave and water level data available (Figure 1).

Exposed fully to the Atlantic Ocean on the east, the town is subjected to high-energy waves predominantly from the northeast direction with mean significant wave heights exceeding $1.3 \mathrm{~m}$ at $17.4 \mathrm{~m}$ depth (1985 - 2016, USACE FRF). Ocean tides are semidiurnal with a mean range of $0.97 \mathrm{~m}$ and a spring tidal range of $1.3 \mathrm{~m}$ (NOAA Duck Gage). Net shoreline change in the community varies between $0.23 \mathrm{~m} / \mathrm{yr}$ (accretion) at the north to $2.18 \mathrm{~m} / \mathrm{yr}$ (erosion) at the southernmost part of the town (NCDENR, 2012).

Over the past two decades the town has undergone two significant beach protection projects: (1) a dune restoration project (2004-2005) due to dune erosion caused by Hurricane Isabel, and (2) the Town of Nags Head Beach Nourishment Project in 2011 to replenish the sand that had been washed away by chronic erosion (Kaczkowski and Kana, 2012). The latter was the largest locallyfunded beach nourishment project in the U.S. by the time of its completion (CSE 2012). The existence of a major locally funded project enables town-based decision-making processes to be used

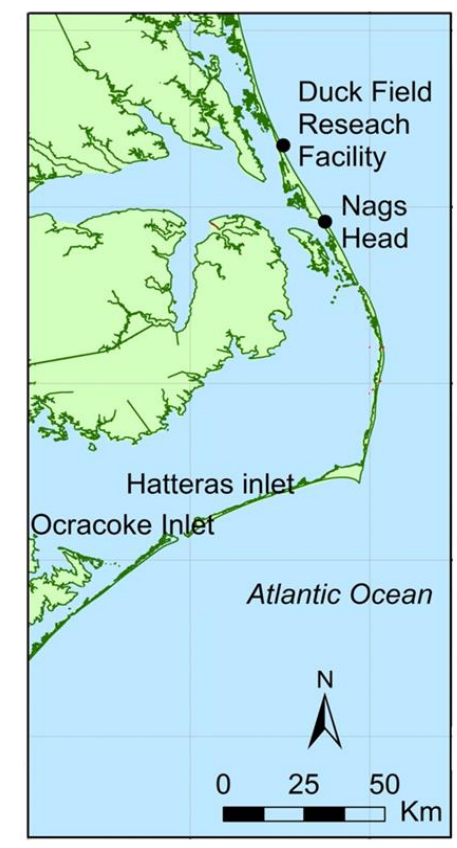

Figure 1. Nags Head location in Outer Banks 
in the model for nourishment projects which simplifies the model by removing federal government decision-making considerations on these projects.

According to the U.S. Census Bureau, the population of Nags Head in 2010 was 2,757 occupying 1,223 of 4,884 available housing units, or $25 \%$ of the total capacity. Nags Head's occupancy rate exhibits a $7.5 \%$ increase over the 2000 household occupancy of 1,138 and indicates a growing community which indicates that the community is not facing a preexisting challenge that can cause difficulties in initialization of the model (U.S. Census Bureau 2000, 2010).

In 1998, dune crest elevations over the study area ranged between approximately 3.5 to $8 \mathrm{~m}$ above the North American Vertical Datum of 1998 (NAVD88). Several stretches of dunes were wiped out during Hurricane Isabel in 2003 and were built up to $4 \mathrm{~m}$ during the dune restoration project carried out between 2004-2005. Currently they stand between 4 to $8 \mathrm{~m}$ (NAVD88). The majority of the land at the hinterland of the dunes is low-lying with elevations approximately $3 \mathrm{~m}$ (NAVD88).

\section{AGENT BASED MODEL DESCRIPTION}

\section{Overview}

ABM provides a tool to study interactions between social systems and natural environment by explicitly modeling interacting agents (Filatova et al., 2011). Individual agents interact with each other and their environment to model the behavior of the whole system. NetLogo (Wilensky, 1999), an opensource software platform, was used to develop a coupled human-natural processes ABM framework for the coastal town which can be used to investigate a range of sea level rise, storm scenarios, management options and their implications (Karanci et al., in press).

The coupled coastal town model consists of three submodels: natural processes, household decisions, and beach management. Model has two exogenous processes: sea level rise and storms. As an improvement to the previous model the influences of storm activity on the natural processes and household decisions submodels are estimated using XBeach in the present study. The overall model structure and the component interactions are represented in Figure 2, with the model environment and component details described in the following sections.

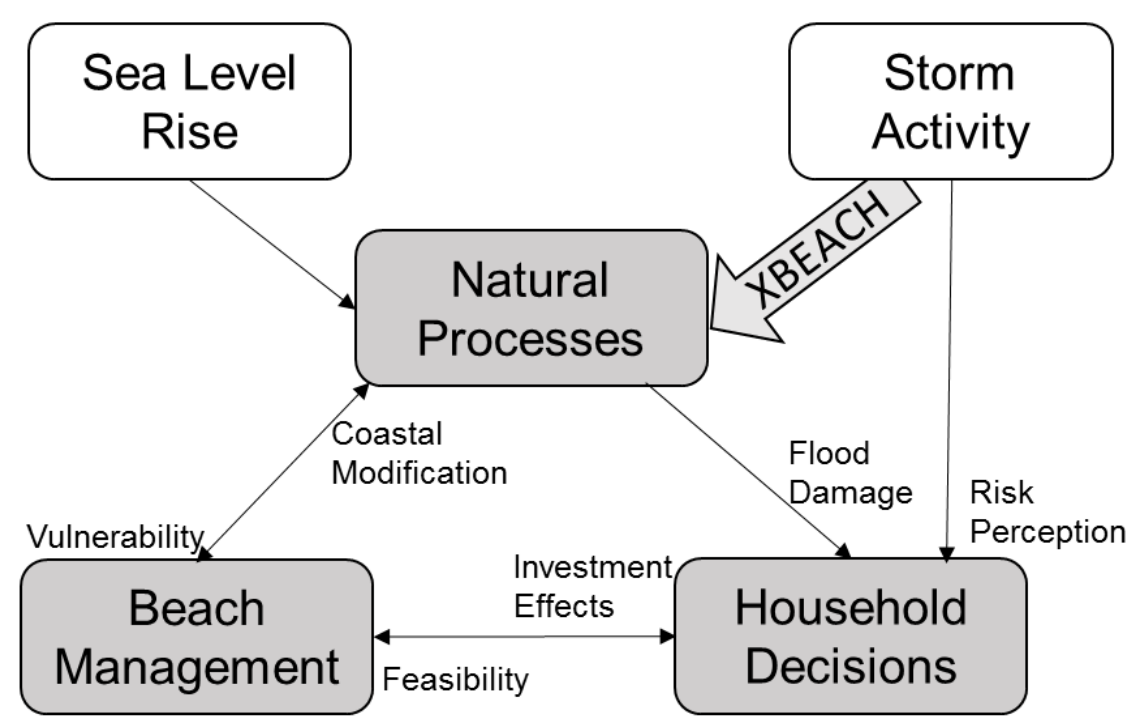

Figure 2. Model structure and component interactions (adapted from Karanci et al., in press).

\section{The Model Environment}

The model environment represents the coastal morphology and cadastral features of a coastal community. In the model, the coastal community is composed of contiguous alongshore cells that represents the spatial variability of subaerial beach morphology and location of cadastral parcels and their land use. Alongshore cells extend from depth of closure to hinterland. Thus the beach, the cadastral parcels, and structures at the hinterland are represented in each cell.

The model uses cadastral parcels to represent the human processes taking place in the community. Cadastral parcels are characterized by land value and land use: empty, residential, commercial and governmental. The parcels which contain structures also have a second set of attributes related to the 
structures: distance from shoreline (mean sea level), first floor elevation (NAVD88), structure age, and property value. In this study, the focus is on household decisions, therefore the state of government and commercial cadastral parcels are assumed to remain constant through simulation time.

To simulate the morphological changes through time, the ABM requires a characterization of the profile extending from closure depth to the heel of the dune for each alongshore cell that includes the key features for natural processes and manipulations due to soft engineered coastal protection projects: beach nourishment and dune replenishment. The ABM performs the soft engineered coastal protection projects using a geometrical representation of the subaerial profile. Consequently, a subaerial profile defined by key points that can be used to represent the protection projects while providing a sufficiently detailed explanation of dune and beach properties for XBeach was required. A simplified representative profile depicting a beach with a trapezoidal dune and a mild sloped berm is used in the ABM (Figure 3). The submerged portion of the profile is represented through a detailed set of points. The variation in detail between the sub-aerial profile and the submerged profile was allowed since the complex submerged profile is assumed to maintain a constant shape, assumed to approximate an equilibrium profile, through the simulation time thus would not require manipulations. The representative subaerial profile consists of the following shore features:

1. Beach slope: The beach slope from the berm to mean sea level.

2. Dune elevation: The elevation of the dune (NAVD88).

3. Dune crest width: The width of the top of the dune.

4. Seaward dune slope: The seaward slope of the dune.

5. Landward dune slope: The landward slope of the dune.

6. Berm elevation: The elevation of the dune (NAVD88).

7. Berm width: The horizontal distance between berm and toe.

8. Toe elevation: The elevation of the dune (NAVD88).

9. Heel elevation: The elevation of the heel of the dune (also assumed as the upland height of the beach profile landward of the dune)

10. Origin (0): The midpoint of the first oceanside road.

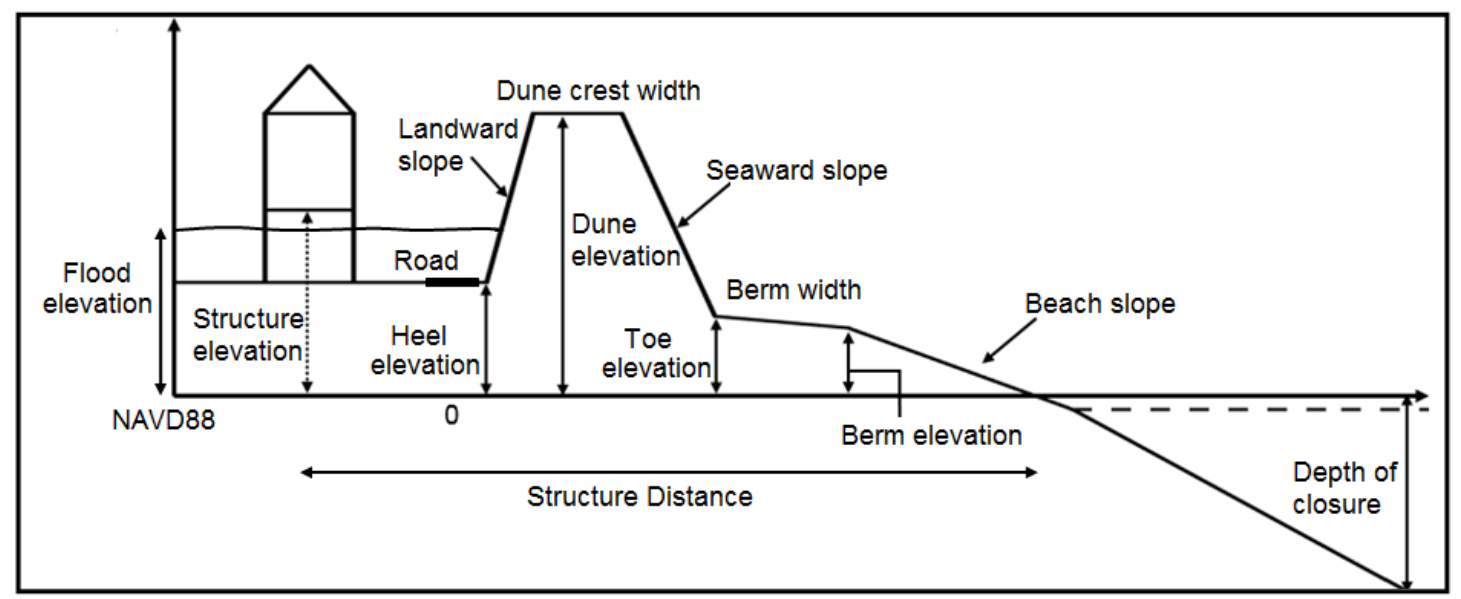

Figure 3. Cross-shore profile representation.

\section{Natural Processes Submodel}

The natural processes submodel simulates morphological changes by modifying the location of representative profile points of each alongshore cell with sea level rise, erosion, and storm impact. In the model the slower processes of erosion and sea level rise are applied at the beginning of each simulated year, whereas storms are forced at random intervals using XBeach simulations. The modeled processes are explained in following sections.

\section{Sea Level Rise}

The model uses the Bruun rule (Bruun 1962) to estimate the shoreline recession corresponding to the increase in the sea level using relative sea level rise rates. The Bruun Rule assumes an equilibrium beach profile and estimates the recession and upward translation of the shoreface. At the start of each time step the segment of the representative profile from berm to depth of closure is moved landward by the recession amount and moved upward by the vertical rise in sea level over the time. 


\section{Erosion}

Changes in shoreline position in the model are simulated through erosion rates (recession/accretion), which are assumed to remain constant throughout the simulation time. At the start of each year, the representative profile from berm to depth of closure is moved landward an amount corresponding to the erosion rate assigned to the alongshore cell multiplied by time step.

\section{Storm Impact}

Storm events are important drivers in the model, causing changes in the profile, damages to structures, and increasing storm awareness of households. The model uses four different storm recurrence intervals to represent storm intensity $(5,10,25$, and 50 years).

As described previously, in the present study XBeach is used in the model to simulate storm impact. When a storm is simulated in the ABM, XBeach is applied in one dimension to determine the cross-shore evolution of the representative profile and storm induced flood levels for each alongshore cell. To provide an input cross-shore profile for the XBeach model the representative profile features in the ABM are used to generate a subaerial grid with varying spacing ( $1 \mathrm{~m}$ at shore to 30 meters hinterland) for each alongshore cell. The generated grid is then merged with the submerged profile and is used as the prestorm profile in XBeach.

The post storm profile in the ABM is obtained by first determining the representative profile features (dune crest width and elevation, dune slopes, toe and berm elevations, and beach slope) on the XBeach post-storm profile and then updating the corresponding feature properties in the ABM. In addition, in the instances of dune removal and overtopping the flood depths at the hinterland are also recorded.

\section{Household Decisions Submodel}

Three types of agents are used in the household decisions submodel: "homeowners", "homebuyers", and "homesellers". The model simulates household's decisions to buy or sell houses and buy insurance according to economic factors and the household's perception of flood risk.

Homeowners stay in their homes depending on their capability to keep up with their mortgage, housing related fees, and damages incurred due to flooding. Damages to structures during a storm are estimated by depth-damage curves (Davis and Skaggs, 1992), for structures with wooden pile foundations. Depth-damage curves relate the value of damage inflicted upon each structure in the alongshore cell based on the simulated flood depth from XBeach, the property value, and the first floor elevation of the structure. If household's expenses are higher than 50\% of annual income, homeowner agents decide to sell their houses and become a homeseller agent.

The household insurance decision is based on the cost of insurance and the expected damage from flooding. The expected damage of a household depends on the perceived frequency and expected severity of storms. Homeowners' perception of storm frequency $\left(\mathrm{P}_{\text {st }}\right)$ depends on the storm events that households can recall in recent memory. The perceived frequency per year is given by:

$$
P_{s t}=\frac{N_{s t}}{t_{m}}
$$

where $t_{m}$ is the timeframe homeowners recall storms (years), $N_{s t}$ is the total number of storms in the timeframe. The perceived fraction of damage from storms $\left(\mathrm{P}_{\mathrm{d}}\right)$ is:

$$
P_{d}=P_{s t} \sum_{i} p_{i} d_{i}
$$

where $\mathrm{i}$ is the index for storm categories $\left(5,10,25\right.$ and 50 return period storms) in the model, $\mathrm{p}_{\mathrm{i}}$ is the probability of the storm, and $d_{i}$ is fraction of damage caused by i return period storm. If the cost of insurance is high relative to the damage expected, households do not buy insurance.

A community's attractiveness for potential homebuyers varies over time. In the model, the attractiveness is assumed to be based on three feedbacks: housing density, expenses, and perceived relative flood risk. In a dense community with few available housing options, housing prices are relatively expensive. Crowded towns can deter people from relocating into the community (Fujita, 1989). On the other hand, deserted towns will be less attractive for businesses and will lead to unemployment for its residents. The model uses housing density, the ratio of occupied parcels to total number of available parcels, to include housing feedback. Potential homebuyers perceive a community crowded if the housing density is higher than the initial value for the simulated period (Franck, 2009). High expenses due to tax rates, flood damage, and high insurance premiums can also discourage homebuyers from purchasing housing. The ratio of average income to average household expense is used to represent this feedback. In the model, the perceived flood risk is a calculated by normalizing the perceived fraction of damage (Eq. 2) by the expected fraction of damage which utilizes the community's actual annual storm 
frequency to determine the expected damage. Perceived relative flood risk, housing density, and town expenses are multiplied to compute the attractiveness of the community. The number of homebuyer agents is determined by the community attractiveness and the historical immigration rate. The new homebuyers first seek empty buildings and then look for available parcels.

\section{Beach Management Submodel}

The beach management submodel represents the town manager agent and is responsible for initiating, planning, implementing, and financing of management measures. The town agent is a rational agent and bases the management decisions on feasibility analysis, which involves economic and physical modeling analyses. The model provides two different management alternatives, planned nourishment and emergency replenishment.

Planned nourishment is a locally funded, preventive protection measure, which is carried out at regular intervals. This option also includes replenishment of the dunes if found necessary. Once the specified nourishment interval has been satisfied, the town manager monitors the subaerial morphology to locate vulnerable sections based on minimum thresholds of cross-sectional dune area, dune height and beach width which can be varied in the model. The manager assesses the feasibility of dune replenishment and beach nourishment. If undertaking of a protection project is not found feasible, the manager re-evaluates next year.

In a beach nourishment project, sand is taken from external sources and placed on the beach, from the berm to the depth of closure. The amount of sand required for a project depends on the difference between the existing beach width and design beach width, berm height, and depth of closure.

The town manager agent uses benefit-cost analysis to assess the feasibility of a nourishment project. Nourishment costs include fixed costs incurred from surveying, planning, mobilizing, dredging, and obtaining permits and variable costs, which depend on the amount of sand necessary for the project.

Property values in the community increase when the beaches become wider. The hedonic pricing model on coastal properties discussed in McNamara et al. (2015), is used to relate the property value and beach width.

$$
B=\int_{0}^{t_{r n}} e^{\delta t} \delta A \cdot x(t)^{\beta}
$$

where $\mathrm{A}$ is the baseline value which includes all attributes of that property except the beach width, $\mathrm{x}$ is the beach width at time $\mathrm{t}, \beta$ controls the capitalized value of beach width, $\mathrm{t}_{\mathrm{rn}}$ is the renourishment interval and $\delta$ is the discount rate for future benefits. The benefits determined are then compared with the estimated costs of the project to decide if the beach nourishment project is beneficial.

During storms, dunes act as a barrier against flooding, and are essential for protection. In the model when a beach nourishment project is undertaken the dunes with insufficient sand in their reservoirs are also located and replenished. The threshold dimensions are determined by performing XBeach simulations with the design storm, selected according to historical storms in the area, and a suite of representative profiles. Consequently, the representative profile features (dune area and dune elevation), which demonstrate dune removal, are considered to provide inadequate protection against flooding and minimum dune dimensions that were able to prevent dune removal were used as thresholds dimensions.

The emergency replenishment alternative is taken after damaging storms where the subaerial morphology is significantly altered and dunes are removed. $75 \%$ of the costs incurred by emergency replenishment are funded by FEMA. The dunes are designed to provide protection against 5-year storms based on FEMA emergency flood-protection criteria.

The incurred costs from the management projects are paid through occupancy and property taxes through the re-nourishment interval. Because the management projects will benefit the houses closer to the coast a tax distribution scheme was devised, in which the amount of burden decreases for the households that are located further from the beach.

\section{MODEL PARAMETRIZATION}

The ABM represents a theoretical coastal community and was initialized with parameters to depict the Town of Nags Head (Figure 4). The initialization year was selected as 1998, due to availability of detailed structure data (Overton et al., 1999). The model includes storms and sea level rise as external drivers of morphological change. The simulation time horizon is 50 years, providing an opportunity to observe several coastal protection actions, possible effects of accelerated sea level rise and rare events, such as a 50-year storm. Time advances through increments of one year during which beach morphology is modified by natural processes, decisions are made by households to buy/sell property and buy/not buy insurance, and town managers decide whether to implement protection projects. 


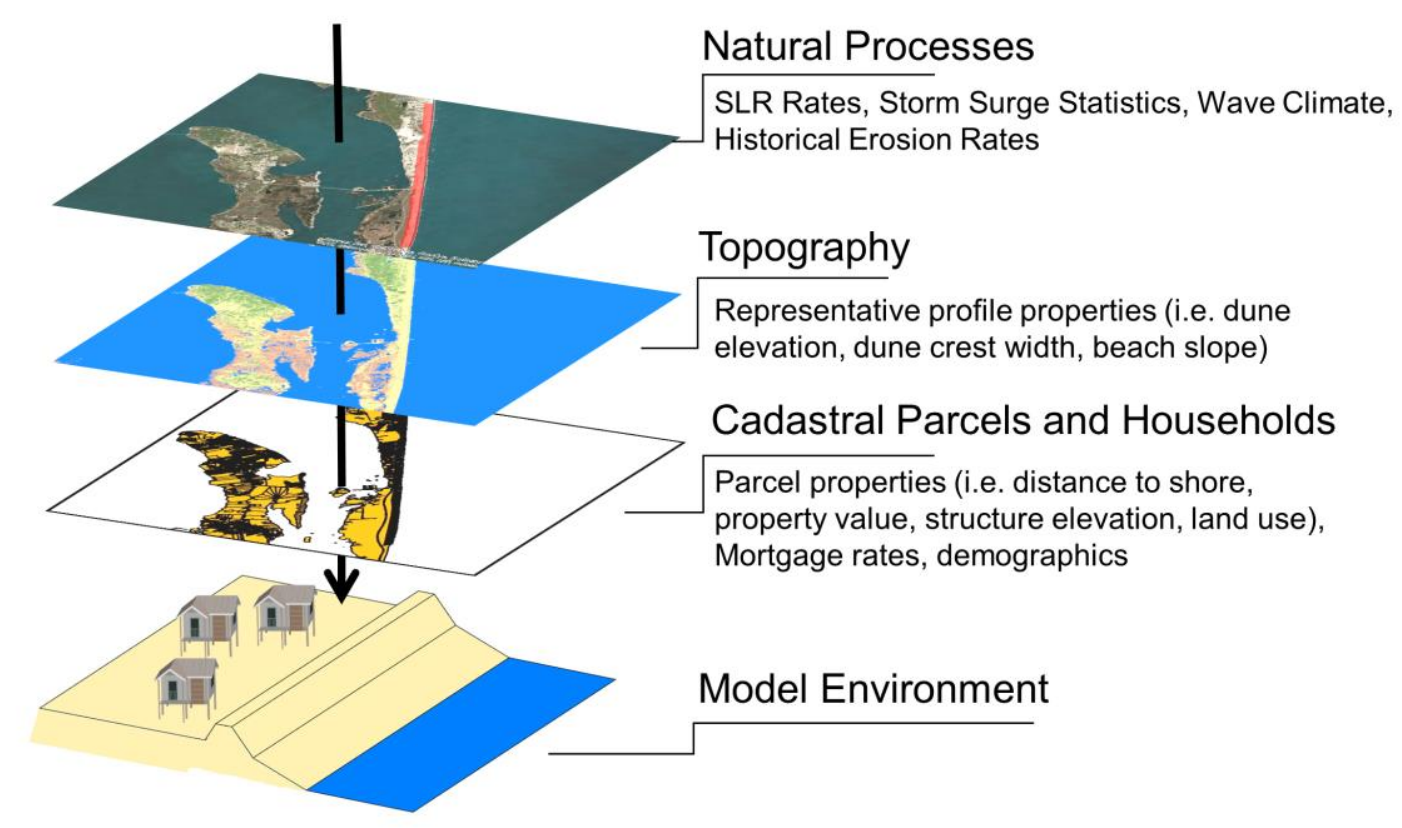

Figure 4. Parameters used to initialize the model.

\section{ABM Environment Parametrization}

The Nags Head study area was divided into 169 cells of approximately $100 \mathrm{~m}$ length alongshore, each cell including at least five cadastral parcels. LiDAR generated for the 1998 Fall East Coast NOAA/USGS/NASA Airborne LiDAR Assessment of Coastal Erosion (ALACE) Project for the U.S. coastline was used to determine the representative subaerial profile features for each alongshore cell (Hardin et al., 2012). The shoreline was placed at mean sea level (-0.13 m NAVD88) (U.S. Army Corps of Engineers, FRF Station) whereas toe elevation was established as $1.8 \mathrm{~m}$ (NAVD88) (Kana and Kaczkowski, 2012). The profiles from 1998 lacked berm features, thus the berm was assumed to be at the same location as the toe during initialization. The heel of the dune was placed at the right-of-way of the most seaward road at an elevation of $2.5 \mathrm{~m}$ (NAVD88) over the study area, which is approximately consistent with the 1998 elevation of Nags Head.

The submerged part of the profile extends to $-17 \mathrm{~m}$ depth and is represented by a detailed series of points with varying spacing. The integrated topographic/bathymetric Digital Elevation Model (DEM) of coastal North Carolina created as part of State of North Carolina Emergency Management Floodplain Modernization Program, was used as the basis for development of submerged profiles (NCFMP, 2006).

Each parcel was attributed a land use, distance from shore, first floor elevation, structure age, land and property value determined from data collection study conducted by Overton et al. (1999) and Dare County tax records. Using the shoreline determined by extracting the $-0.13 \mathrm{~m}$ (NAVD88) contour from the DEM, the structures' distances from shore were also recorded.

\section{Natural Processes Submodel Parametrization}

\section{Erosion}

Long-term erosion rates $(\mathrm{m} / \mathrm{yr})$ were gathered from the GIS database of the N.C. Department of Environment and Natural Resources (NCDENR, 2012). The erosion rates were adjusted to remove the recession due to sea level rise, because it is accounted for in the sea level rise forcing component of the model. Each cell in the study area was assigned an annual adjusted erosion rate corresponding to these data.

\section{Storm Impact Scenarios-XBeach parametrization}

Three 50-year-long storm timeline scenarios were developed to investigate the effect of a varying stochastic storm on household dynamics and town decisions. The scenarios consisted of identical storm occurrences with the exception of one synthetic storm with varying recurrence interval (10-year, 25-year, or 50-year) occurring in Year 25. The intensities were varied for that one storm to isolate emergent trends caused by a particular storm event. The scenario storm was placed at the middle of the simulation time, 
to provide time before and after the storm within the simulation to inspect the household occupation trends and recognize possible changes in between them. In addition, placing the storm in the middle of the simulation allows the town to take protective management action if town managers deem necessary.

The base storm timeline for the simulations was developed using historical storm data from the USACE FRF pier directional waverider located $3 \mathrm{~km}$ offshore. The waverider has been in operation for a time period of 29 years, from 1987 to 2016. During that time, 274 storm events were observed (defined as events with a wave height of $2 \mathrm{~m}$ or greater and a duration of 8 hours). These events were binned according to recurrence interval as determined by FEMA flood insurance study for Dare County (FEMA, 2006). The probability of occurrence of each storm during the 50-year timeframe was determined using a Poisson probability distribution function. The results indicated that over any given 50-year time period, various 5-year and 10-year storms will occur, as well as a single 25-year storm. Therefore, seven 5-year and two 10-year storms were distributed randomly throughout the 50-year base simulation period using a physical random number generator (Haar, 1998). The highest intensity storm recorded, 25-year storm (Hurricane Isabel), was exchanged with a scenario storm and was not included in the generation of base simulation period.

Three synthetic storms of varying intensity (10-year, 25-year, or 50-year return period) were then added to the base storm timeline at year 25 to produce the three simulation storm timelines (Figure 5).

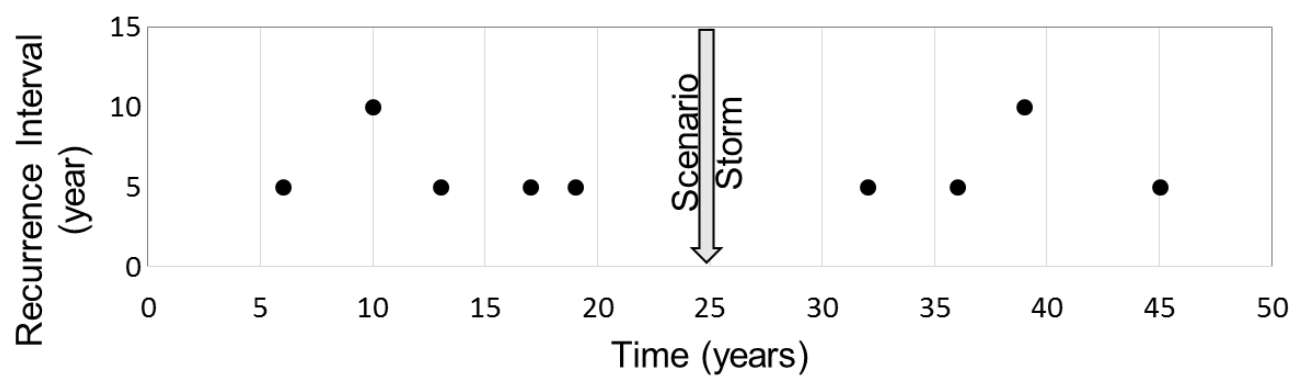

Figure 5. Storm arrival time line. Scenario storm is a 10 -year storm for scenario 1,25 -year storm for scenario 2 , and 50 -year storm for scenario 3.

The time dependent XBeach inputs are the beach profile, wave height, wave period, and sea level. For this study, the wave input files were created as hourly Jonswap spectra and the sea level input was created as an hourly record. The model makes use of historical storm records in the study area to generate synthetic storm properties (water level and wave records).

Still water flood levels (SWFL) corresponding to the return periods of the synthetic storms over Town of Nags Head were determined from the Dare County FIS (FEMA, 2006) (Table 1). A synthetic storm surge hydrograph method was used (Zevenbergen et al., 2004) to generate time-dependent surge values that can were used in the XBeach simulations. Using this deterministic approach and the still water flood levels, synthetic hydrographs were developed with peaks at the respective SWFLs.

\begin{tabular}{|c|c|}
\hline \multicolumn{2}{|c|}{ Table 1. Still water flood levels of model storms. } \\
\hline Return Period (year) & SWFL (m, NAVD) \\
\hline 5 & 1.123 \\
10 & 1.410 \\
25 & 1.660 \\
50 & 1.849 \\
\hline
\end{tabular}

To estimate extreme wave heights and storm durations for different return period storms, Weibull (3 parameters), Fréchet, Gumbel and the lognormal distributions were employed (Goda, 2010). Wave heights and storm durations were fitted to these distributions and compared using linear least squares interpolation. In both cases, the Weibull distribution fit the FRF data better than the other distributions. Assuming the distribution of wave heights within a storm follows the accepted Rayleigh distribution, the wave periods were calculated by relating wave height to period of the Pierson-Moskowitz spectrum. The wave heights, periods and storm durations corresponding to return periods are given in Table 2 . 


\begin{tabular}{|c|c|c|c|c|}
\hline Return Period (year) & 5 & 10 & 25 & 50 \\
\hline Significant Wave Height (m) & 2.4 & 3.5 & 5.2 & 6.6 \\
\hline Wave Period (sec) & 6.7 & 9.3 & 11.4 & 14.1 \\
\hline Storm Duration (hrs) & 19 & 25 & 57 & 72 \\
\hline
\end{tabular}

After the wave height, period, and duration of the events were specified the time distribution of wave heights is generated. Although storms follow the familiar shape of a hydrograph with rising and falling limbs, each storm has a unique pattern of wave heights. The procedure described by Dorsch et al. (2008), adapted from The Representative Rainfall Temporal Patterns (RRTP) method (Wu, Yang and Tung, 2006), was employed to develop dimensionless representative temporal patterns that distribute wave heights over a storm event, independent of storm duration. The representative temporal pattern was then converted into time-dependent wave records for each synthetic storm using the cumulative wave heightstorm duration relationship and Rayleigh distribution (Longuet-Higgins, 1952).

\section{Sea Level Rise Scenarios and Parametrization}

To explore the influence of sea level rise on household dynamics three sea level rise scenarios were defined in this model: constant sea level rise, low emission (RCP2.6) and high emission (RCP8.5) sea level rise projections in IPCC (2013) and (Church et al. 2013). For the Town of Nags Head, sea level rise was initialized at $0.457 \mathrm{~cm} / \mathrm{yr}$, and was kept constant until year 15 the in simulation (corresponding to 2013) based on the long term sea level rise measurement calculated at the Duck NOAA tide gauge (1978 - 2013). In addition to the initial sea level rise rate, the model allowed for sea level rise acceleration which can be used to account for global sea level changes, due to thermal expansion and deglaciation. The low and high emission scenarios reported in IPCC (2013) are used to account for the lowest and highest estimated rates of accelerated sea level rise. To estimate the relative sea level rise after year 15, vertical movement of the Earth's crust (N.C. Coastal Resources Commission's Science Panel on Coastal Hazards, 2015) was added to global sea level rise estimations reported in the IPCC (2013) (Table 3).

\begin{tabular}{|c|c|c|c|}
\hline \multicolumn{4}{|c|}{ Table 3. Relative sea level rise for scenarios (cm). } \\
\hline Year & Constant SLR & RCP2.6 (mean) & RCP8.5 (mean) \\
\hline 0 & 0 & 0 & 0 \\
10 & 4.6 & 4.6 & 4.6 \\
20 & 9.1 & 9.3 & 9.3 \\
30 & 13.7 & 15.6 & 15.6 \\
40 & 18.3 & 21.4 & 23.0 \\
50 & 22.9 & 29.1 & 31.9 \\
\hline
\end{tabular}

\section{Beach Management Sub-model Parametrization}

In the beach management submodel, the town manager agent locates and replenishes the vulnerable locations that are found feasible based on the thresholds attributed to beach width (between MSL and berm) and cross-shore dune area extending from toe to heel. Threshold beach width for nourishment was selected as the width required to prevent run-up from exceeding the berm. Using Holman (1986) to compute estimated run-up, the threshold beach width was assigned in the model as $20 \mathrm{~m}$.

During dune replenishment projects, the model locates and replenishes the dunes that are vulnerable against the design storm. The 25-year synthetic storm, equivalent to the highest intensity storm recorded at the USACE FRF, was selected as the design storm for planned dune replenishment projects. To determine the threshold dune dimensions XBeach runs were performed with varying subaerial profiles using the 25-year synthetic storm (Table 1-2). The threshold for the minimum dune area in the model ensuring protection for structures behind was determined as $40 \mathrm{~m}^{3} / \mathrm{m}$. Using the XBeach simulations, the design dune profile was established and has a $4.5 \mathrm{~m}$ (NAVD88) dune crest elevation; 1:5 frontal slope; 1:3 landward slope and $8 \mathrm{~m}$ crest width. The dune profile begins at the heel of the original dune and extends seaward with a $15 \mathrm{~m}$ wide berm at $1.8 \mathrm{~m}$ (NAVD88) elevation, located seaward of the toe.

Additionally, an emergency replenishment project, funded by FEMA, can be carried out after storms. The dunes in emergency replenishment projects are designed to withstand 5-year storms (FEMA, 2006). As in the planned replenishment project, dimensions of the emergency project were also selected according to XBeach simulations with a 5-year return period storm (Table 1-2). During the emergency project, the removed dunes are located and a triangular dune with $3.5 \mathrm{~m}$ (NAVD88) dune crest elevation, 
1:5 frontal slope, and 1:3 landward slope is built. The definitions and values of additional model parameters and references are specified in Table 4.

\begin{tabular}{|lll|}
\hline $\begin{array}{l}\text { Table 4. Parameters of the beach management submodel (monetary values are in U.S. Dollars) } \\
\text { (Karanci et al., in press) }\end{array}$ \\
\hline Definition & Value & Reference \\
\hline Fixed nourishment-replenishment costs & $\$ 1,200,000$ & Coastal Science and \\
Variable costs (sand) & $16.34 \$ / \mathrm{m}^{3}$ & Engineering, 2012 \\
Re-nourishment interval & $5 \mathrm{yr}$ & \\
Discount rate & $0.06 \%$ & Smith et al., 2009 \\
Hedonic price of beach width & 0.5 & \\
Base property value excluding beach & $\$ 100,000$ & Karanci et al., in.press \\
width influence & $30 \mathrm{~m}$ & \\
Design beach width & &
\end{tabular}

\section{Household Decisions Submodel Parametrization}

The household decisions submodel represents household actions based on economic evaluations or perceptions of risk. The submodel is initialized with 1,121 households to reflect 1998 household conditions based on U.S. Census Bureau estimations (2000). The definitions and values of household submodel parameters and references are specified in Table 5.

\begin{tabular}{|lll|}
\hline $\begin{array}{l}\text { Table 5. Parameters of the household decisions submodel (monetary values are in U.S. } \\
\text { Dollars) (Karanci et al., in press) }\end{array}$ & \\
\hline Definition & Value & Reference \\
\hline Rate of household immigration & 30 households/yr & U.S. Census Bureau 2000 \\
Annual interest rate & $0.035 \%$ & FHA, 2014 \\
Mortgage duration & $30 \mathrm{yr}$ & U.S. HUD, 2016 \\
Principal loan & $0.85{ }^{*}$ property value & Putra et al., 2015 \\
Insurance coverage & $\$ 250,000$ & FEMA, 2016 \\
Storm recall time interval, $\mathrm{t}_{\mathrm{m}}$ & $5 \mathrm{yr}$ & De Waard, 2015 \\
\hline
\end{tabular}

\section{RESULTS}

\section{Storm Scenarios}

Storm events can cause shocks to the system that can put significant stresses on the coastal communities producing changes in occupation dynamics. The results from forcing the model with the three storm timeline scenarios and IPCC (2013) low emission scenario are presented in Figure 6. During the first 25 years, all three simulated communities face the same conditions and therefore respond identically. Households start occupying the empty parcels while communities undergo nourishment and emergency replenishment projects to mitigate hazards. In scenario 1 , the community is faced with a 10 year storm at year 25 , with most of the storm impacts absorbed by the dunes. The community is able to recover quickly and continues to grow. In scenario 2, the community experiences a 25-year storm, which causes some households to leave. The community undergoes an emergency dune replenishment project and the community's attractiveness increases as memory of the storm fades. It is able to withstand following storms without incurring significant changes to its attractiveness. At the end of the 50-year simulation its attractiveness keeps increasing. In the third scenario, a 50-year storm arrives at year 25 , damage is more extensive, and more houses are abandoned. Increased risk perception, as well as protection and recovery costs suppress community attractiveness and hinder growth. This can be defined as a tipping point where the community stagnates with respect to its occupation. The 10 -year storm which arrives at year 38, causes damage and abandonment in scenario 3 due to diminished natural protection which combined with higher expenses and increased risk perception prevents community's growth. 


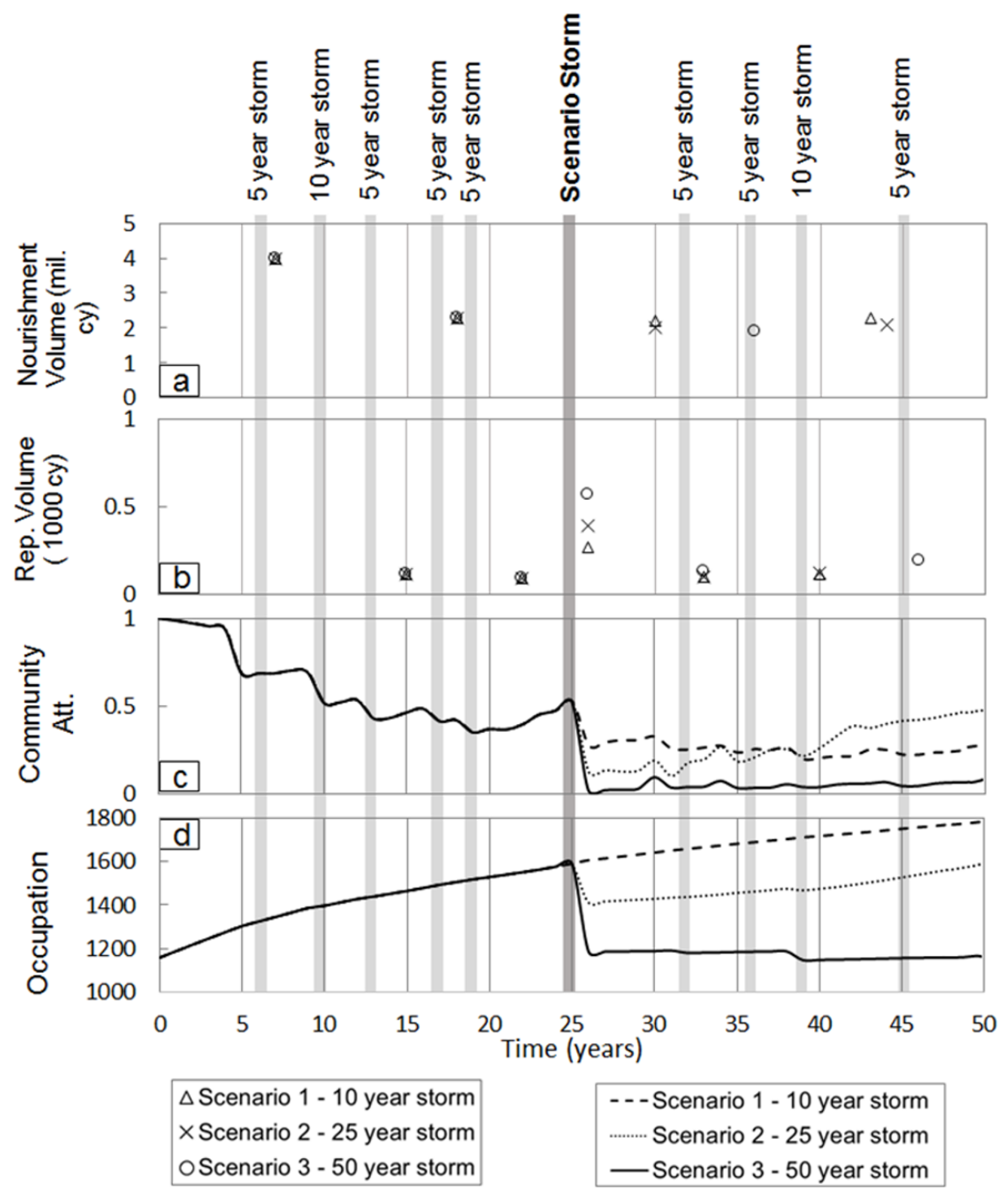

Figure 6-Time series of: a. planned nourishment sand volumes (million cy), b. emergency dune replenishment sand volume (1000 cy), c. community attractiveness, and d. occupied households in the community.

Protection decisions are also influenced by the change in occupation in different scenarios. As the size of the community grows, the number of properties that will benefit from a protection project increases and the protection becomes more feasible. A larger community also provides a bigger property tax base, making the projects easier to fund. Although all communities are able to implement an emergency replenishment project using funding from FEMA immediately after year 25, their decisions to undertake locally funded projects differ. In the first two scenarios, both communities undergo similar protection activities and are able to protect their residents whereas the stagnating community of scenario 3 must wait seven years in order to be able to undergo a nourishment project.

\section{Sea Level Rise}

Sea level rise accelerates the erosion of shorelines, moves the shoreline closer to structures and increases elevation of mean sea level. Although the influence of climate change on storminess is debated, with sea levels increasing the potential risk of flooding is magnified due to an increase in storm surge levels (Mcinnes et al., 2003). To investigate the possible influence of sea level rise rates on the community occupancy dynamics, storm scenario 1, with a 10-year storm at year 25, was simulated with varying sea level rise scenarios, with relative sea levels presented in Table 3. Storm scenario 1 was chosen due to the absence of a tipping point in its simulation timeline. Therefore, any occurrence of a tipping point in these scenarios can be attributed to sea level rise. To serve as a baseline, a scenario with no sea level rise was also explored (Figure 7). 


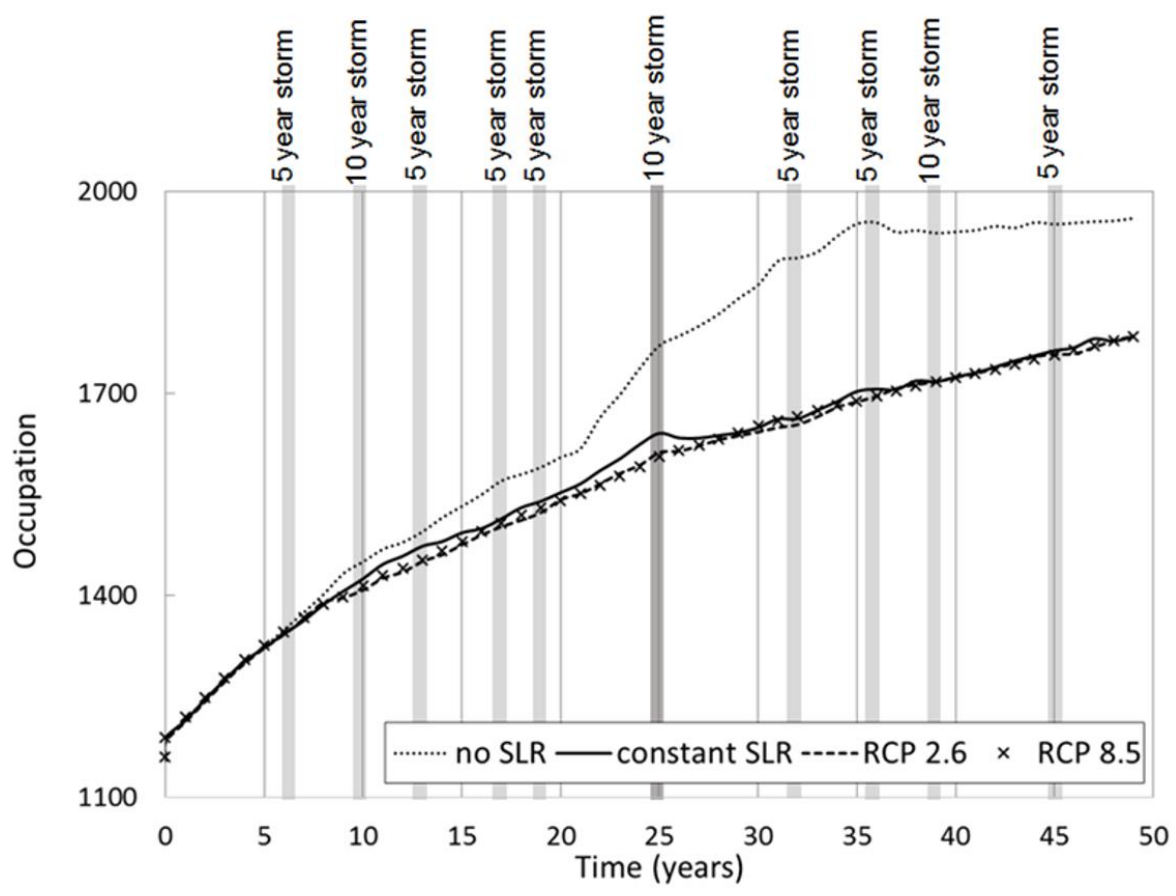

Figure 7 - Time varying household occupation during different sea level rise alternatives.

Figure 7 shows that the baseline scenario with no sea level rise produces a significant variation of household occupation numbers compared to other cases. With sea levels approximately $0.1 \mathrm{~m}$ lower than the other scenarios at the middle of the simulation time, the baseline scenario depicts a more attractive community with less vulnerable houses, as the first floor elevations are higher relative to mean sea level compared to other scenarios.

Moreover with no sea level rise accelerating the shoreline recession, nourishment projects at the baseline community requires less sand, and thus expenses of the households are lower (Table 6). Table 6 shows, (1) how much recession was caused by sea level rise for scenarios that exhibit higher sea level rise and (2) the corresponding cost of sand to return the shoreline to its original position throughout the town by carrying out nourishment projects.

Results show that, towns are able to mitigate the recession caused by sea level rise through beach nourishment projects. Thus, the households do not lose their houses to the sea, but they are affected through the rise in taxes due to the increase in sand required for nourishment projects. As the expenses increase, immigration to the community decreases and the communities in scenarios with sea level rise show slower growth. As shown in Table 6, even when a constant sea level rise scenario is considered, the community spends more than 1 million dollars by year 30 on sand to keep the shoreline at the same position as the community with no sea level rise.

\begin{tabular}{|c|c|c|c|c|c|c|}
\hline \multirow[b]{2}{*}{ Year } & \multicolumn{2}{|c|}{ Constant SLR } & \multicolumn{2}{|c|}{ RCP2.6 (mean) } & \multicolumn{2}{|c|}{ RCP8.5 (mean) } \\
\hline & Recession (m) & $\begin{array}{l}\text { Cost of sand } \\
\text { lost (mil. \$) }\end{array}$ & Recession (m) & $\begin{array}{l}\text { Cost of sand } \\
\text { lost (mil. \$) }\end{array}$ & Recession (m) & $\begin{array}{l}\text { Cost of sand } \\
\text { lost (mil. \$) }\end{array}$ \\
\hline 0 & 0 & 0 & 0 & 0 & 0 & 0 \\
\hline 10 & 2.29 & 0.35 & 2.29 & 0.35 & 2.29 & 0.35 \\
\hline 20 & 4.58 & 0.71 & 4.66 & 0.72 & 4.66 & 0.72 \\
\hline 30 & 6.87 & 1.06 & 7.81 & 1.21 & 7.81 & 1.21 \\
\hline 40 & 9.16 & 1.42 & 10.71 & 1.66 & 11.53 & 1.78 \\
\hline 50 & 11.45 & 1.77 & 14.59 & 2.26 & 15.99 & 2.47 \\
\hline
\end{tabular}

The three scenarios that include sea level rise, lead to similar results, even though the cost of nourishment varies. This can be attributed to the small range of difference in recession due to sea levels among those scenarios within the simulation time. Additionally, in these three scenarios, storms play a 
more influential role compared to the no sea level rise scenario. As a result of sea level rise, mean sea level elevation is closer to first floor elevations and the dune crests in these scenarios and flooding risk is higher. The relative sea level rise between constant sea level rise, RCP2.6 and RCP8.5 are not significantly different (Table 3) thus escalation of flooding risk due to sea level rise is similar for these scenarios. From Figure 7 it can be seen that the constant SLR scenario (between years 10-16 and 21-25) does show a steeper increasing household occupation trend compared to the IPCC emission scenarios. Consequently, when a storm hits the community, there are more households affected and a higher drop in household numbers is observed compared to IPCC scenarios.

The scenarios presented in this section do not trigger a tipping point. Communities in all scenarios are growing even when the high emission scenario is used. This can be attributed to the nature of gradual and foreseeable expected change caused by sea level rise that provides the community with opportunities to take protective action and avoid facing a disruption in its household dynamics. In addition, in the 50year time frame of the simulations, a relatively small amount of change in sea level rise was observed and the communities were able to mitigate the challenges.

\section{CONCLUSIONS}

Coastal communities are facing increasing challenges due to sea level rise and increasing population and, as a results, have more property at risk from coastal hazards. Although communities might be able to buffer the challenges arising from these changes, abrupt disturbances such as damaging storms might push a community over the tipping point and cause it to lose its vitality. This study improved a previously developed human-natural systems coupled community model by producing a framework to include the process-based model XBeach to estimate morphological storm impact. The study also examined the changes in household occupation dynamics due to storms and sea level rise by simulating plausible scenarios.

The simulations showed a strong link between the intensity of storms and household occupancy. Results suggest that increased storm intensity would hinder development and in some cases cause a community to stagnate or degrade with respect to its occupation. The results also indicate a feedback loop between the natural processes, management decisions, and household decisions. After a high intensity storm, buildings are damaged, expenses are increased and household occupation declines. A diminished community cannot invest in protection measures and in turn becomes more vulnerable to a possible future storm. Explorations of storm scenarios show that for the cases analyzed in this study, the occurrence of a tipping point is sensitive to changes in storm intensity. This result highlights the importance of integrating storm impact into coastal management models.

Four scenarios regarding sea level rise (no sea level rise; constant sea level rise, RCP 2.6 and RCP 8.5) were examined in this study using same the storm arrival timeline to demonstrate the influence of sea level rise on occupation trends. Although the baseline scenario with no sea level rise did show a more attractive community, the remaining scenarios exhibited similar occupancy trends. The difference observed in the baseline scenario was attributed to (1) absence of expenses that were incurred in other scenarios to mitigate recession caused by sea level rise and (2) lower flooding risk because of the higher elevation differences between first floor elevations and mean sea level. In all of the simulated scenarios, communities were capable of mitigating the challenges caused by increasing sea levels and continued to grow. Although the sea level rise scenarios did not exhibit a tipping point in household dynamics, utilizing a different storm scenario with a higher intensity storm could lead to an abrupt, unrecoverable change in household dynamics. In addition, the model does not consider the limitation on sand sources which be exacerbated by the competing demands on nourishment sand put in place by the neighboring towns, which will lead to increased prices.

As described, the model does not include alternative protection projects. Although designs of these projects can change community vulnerability, the overall influence of storm intensity and sea level rise will remain the same. Future model improvements can include alternative protection actions such as bigger dunes, seawalls, or policy actions such as relocation.

The model also does not consider government intervention to community viability. With the exception of emergency dune replenishment funds, the model does not consider other forms of government assistance such as discounted insurance coverage, or financial and logistic assistance, which can help the community to recover from the disturbance to its original state.

There are limitations in the natural processes model employed here as well. Representation of morphology in the model is based on a simplified cross-shore profile and does not include alongshore sediment-fluxes or lateral spreading. Improvements to these assumptions can change the value of results but it is expected that overall dynamics would remain unchanged. 
The model presented in this study can be used as a tool to investigate community behavior under varying management, storm, and sea level conditions and used by local or state government to develop policies to create towns that are more resilient. In future research, the model can be enhanced with the inclusion of additional social phenomena, community attractiveness feedbacks and improved morphological representations.

\section{REFERENCES}

Bruun P. 1962. Sea-level rise as a cause of shore erosion. Journal of the Waterways and Harbors Division, American Society Civil Engineers Proceedings, 88, 117-130.

Church J. A., P. U. Clark, A. Cazenave, J. M. Gregory, S. Jevrejeva, A. Levermann, M. A. Merrifield, G. A. Milne, R. S. Nerem, and P. D. Nunn. 2013. Sea level change. In T. F. Stocker, D. Qin, G. K Plattner, M. Tignor, S. K. Allen, A. Boschung, A. Nauels, Y. Xia, V. Bex, and P. M. Midgley, editors. Climate Change 2013: The Physical Science Basis. Contribution of Working Group I to the Fifth Assessment Report of the Intergovernmental Panel on Climate Change, Cambridge University Press, Cambridge United Kingdom and New York, NY, USA.

Coastal Science and Engineering.2012. 2011 Nags Head Beach Nourishment Project, Nags Head North Carolina. Columbia, SC: Coastal Science and Engineering.

De Waard J. 2016. Quantifying the impacts of climate-driven flood risk changes and risk perception biases on coastal urban property values. University of Twente, Masters Thesis.

Dorsch W., T. Newland, D. Tassone, S. Tymons, and D. Walker. 2008. A statistical approach to modelling the temporal patterns of ocean storms. Journal of Coastal Research, 1430-1438.

Emanuel K. 2005. Increasing destructiveness of tropical cyclones over the past 30 years. Nature, 436, 686-688.

Federal Emergency Management Agency. Flood Insurance Study: A report of flood hazards in Dare County, North Carolina and incorporated areas. Atlanta, GA, USA: Federal Emergency Agency; 2006.

Federal Emergency Management Agency. Policy Rates. Retrieved 08/21, 2016, from https://www.floodsmart.gov/floodsmart/pages/residential_coverage/policy_rates.

Federal Housing Administration (FHA). 2014. Average Interest Rates for FHA-Insured 30-yr Fixed Rate One Living Unit Home Mortgages. Retrieved May, 1, 2016, from http://portal.hud.gov/hudportal/documents/huddoc?id=fharates_current.pdf

Filatova T., A. Voinov, and A. Van Der Veen. 2011. Land market mechanisms for preservation of space for coastal ecosystems: an agent-based analysis. Environmental Modelling \& Software, 26, 179-190.

Franck T.R. 2009. Coastal communities and climate change: a dynamic model of risk perception, storms and adaptation. PhD Dissertation. Massachusetts Institute of Technology; 2009.

Fujita M. 1989. Urban economic theory: land use and city size. Cambridge university press, Cambridge.

Gōda Y. 2010. Random seas and design of maritime structures. World scientific, Singapore.

Haar M. 1998. Random.org. Retrieved August, 15, 2016, from http://random.org/

Hardin E., M. O. Kurum, H. Mitasova, and M. F. Overton. 2012. Least cost path extraction of topographic features for storm impact scale mapping. Journal of Coastal Research, 28,970-978.

Holman R. 1986. Extreme value statistics for wave run-up on a natural beach. Coastal Engineering, 9,527-544.

Intergovernmental Panel on Climate Change (IPCC). 2013. Fifth Assessment Report: Climate Change 2013, The Physical Science Basis.

Kaczkowski H. L., T. W. Kana. 2012. Final design of the Nags Head beach nourishment project using a longshore numerical model. Coastal Engineering Proceedings, 1,64.

Kana, T., Kaczkowski,H. 2012. Planning, preliminary design, and initial performance of the Nags Head beach nourishment project. Coastal Engineering Proceedings, 1.

Karanci A., L. Velasquez-Montoya, J. Paniagua-Arroyave, P. N. Adams, and M.F. Overton. in press. beach management practices and occupation dynamics: an agent-based modeling study for the coastal town of Nags Head, NC, USA. In Beach Management Tools, Springer.

Longuet-Higgins M. S. 1952. On the statistical distribution of the heights of sea waves. Journal of Marine Research, 11-3, 245-263.

McInnes K., K. Walsh, G. Hubbert, and T. Beer. 2003. Impact of sea-level rise and storm surges on a coastal community. Natural Hazards, 30, 187-207. 
McNamara D. E., S. Gopalakrishnan, M. D. Smith, and A. B. Murray. 2015. Climate adaptation and policy-induced inflation of coastal property value. PloS one, 10.

Murray B. A., S. Gopalakrishnan, D. E. McNamara, and M. D. Smith. 2013. Progress in coupling models of human and coastal landscape change. Computers \& Geosciences, 53, 30-38.

North Carolina Department of Environment and Resources (NCDENR). 2012. North Carolina 2011 Long-Term Average Annual Oceanfront Erosion Rates. Raleigh, NC, USA: N.C. Department of Environment and Natural Resources - Division of Coastal Management.

North Carolina Floodplain Mapping Program (NCFMP). 2006. North Carolina Floodplain Mapping Program. http://www.ncfloodmaps.com

North Carolina Coastal Resources Commission Science Panel. 2015. North Carolina sea level rise assesment report 2015.

Overton M., R. Grenier Jr, E. Judge, and J. Fisher. 1999. Identification and analysis of coastal erosion hazard areas: Dare and Brunswick Counties, North Carolina. Journal of Coastal Research, 69-84.

Putra H. C., H. Zhang, and C. Andrews. 2015. Modeling real estate market responses to climate change in the coastal zone. Journal of Artificial Societies and Social Simulation, 18, 18.

Railsback S. F., V. Grimm. 2011. Agent-based and individual-based modeling: a practical introduction. Princeton university press.

Roelvink D., A. Reniers, A. van Dongeren, J. van Thiel de Vries, R. McCall, and J. Lescinski. 2009. Modelling storm impacts on beaches, dunes and barrier islands. Coastal Engineering 56, 1133 1152.

Smith M. D., J. M. Slott, D. McNamara, and A. B. Murray. 2009. Beach nourishment as a dynamic capital accumulation problem. Journal of Environmental Economics and Management, 58, 58-71.

Splinter K. D., M. L. Palmsten. 2012. Modeling dune response to an East Coast Low. Marine Geology, 329, 46-57.

U.S. Census Bureau.2010. Profile of general population and housing characteristics: Nags Head Town, NC.

U.S. Census Bureau. 2000. Profile of general demographic characters: Nags Head Town, NC.

U.S. Department of Housing and Development (HUD). 2016. Buying a Home. Looking for the best mortgage.

Van Dongeren, A., A. Bolle, M.I. Vousdoukas, T. Plomaritis, P. Eftimova, J. Williams, C. Armaroli, D. Idier, P. Van Geer, and J. Van Thiel de Vries. 2009. MICORE: dune erosion and overwash model validation with data from nine European field sites. Proceedings of coastal dynamics.

Wilensky U. 1999. NetLogo. Center for Connected Learning and Computer-Based Modeling. http://ccl.northwestern.edu/netlogo/

Wu S., J. Yang, and Y. Tung. 2006. Identification and stochastic generation of representative rainfall temporal patterns in Hong Kong territory. Stochastic environmental research and risk assessment, 20, 171-183.

Zevenbergen L.W., Lagasse P.F., Edge B.L. Tidal hydrology, hydraulics and scour at bridges. Washington, DC: U.S. Department of Transportation Federal Highway Administration; 2004. Report nr FHWA NHI_HEC-25. 